\title{
Onkologopedia w systemie kształcenia logopedów
}

Oncological Logopaedics In The System Of Speech Therapists' Education

Słowa kluczowe: logopedia, onkologopedia, rak, system kształcenia

Keywords: speech therapy, oncology, cancer, education system

\section{Wprowadzenie}

Nowa specjalność logopedyczna, jaką jest onkologopedia, jest wynikiem wieloletniego kształtowania się logopedii wraz z jej dotychczas powstałymi specjalnościami. Według ostatniego raportu Krajowego Rejestru Nowotworów w 2015 roku odnotowano 4389 zachorowań na raka w obrębie jamy ustnej, 2526 zachorowań na raka krtani i 1411 zachorowań na raka przełyku [Didkowska, Wojciechowska, Olasek, 2017]. Dane te wskazują, jak wiele osób - z uwagi na powstałe zaburzenia mowy i połykania - będzie mogło wymagać wsparcia logopedy. W prezentowanym tekście przedstawiony zostanie zarys rozwoju logopedii oraz proces instytucjonalizacji zawodu logopedy w Polsce, a także rozwój onkologopedii wraz z opisem jej przedmiotu badań. Przytoczone zostaną wyniki badań dotyczących postaw logopedów wobec terapii logopedycznej osób z zaburzeniami mowy i czynności prymarnych o podłożu choroby nowotworowej. Celem artykułu jest ukazanie, że włączenie w system kształcenia logopedów przedmiotów z zakresu onkologopedii jest istotnym kierunkiem rozwoju tej dziedziny.

\footnotetext{
* Katedra Logopedii, Wydział Nauk Pedagogicznych Uniwersytetu Mikołaja Kopernika w Toruniu, ul. Lwowska 1, 87-100 Toruń, e-mail: hamer@umk.pl.
} 


\section{O rozwoju logopedii i instytucjonalizacji zawodu}

Logopedia to dziedzina nauki, która obecnie przeżywa intensywny rozwój. W Polsce jej historia sięga XIX wieku, kiedy to między innymi Benedykt Dylewski, Władysław Ołtuszewski i Jan Siestrzyński rozpoczynali swoje działania na rzecz osób z zaburzeniami mowy [Minczakiewicz, 1998; Dramska, 2001]. Opis historii logopedii od czasów przedwojennych do czasów współczesnych można odnaleźć w artykule Logopedia warszawska - historia i czasy współczesne autorstwa Józefa Porayskiego-Pomsty i Danuty Emiluty-Rozyi [2018]. W latach sześćdziesiątych ubiegłego wieku kolebką polskiej logopedii stał się ośrodek lubelski, gdzie działalność naukową i popularyzatorską rozpowszechniali między innymi Leon Kaczmarek i Józef Kania. Należy jednak wspomnieć, że istniały różne ośrodki logopedyczne, które przyczyniły się do tworzenia polskiej logopedii: warszawski, poznański, śląski, krakowski, gdański [Minczakiewicz, 1998]. Warto także pamiętać o Irenie Styczek, która w 1979 roku napisała pierwszy kluczowy podręcznik - Zarys logopedii. Szczegółowy opis historii rozwoju logopedii w Polsce odnaleźć można między innymi w dwóch monografiach: Początki i rozwój polskiej logopedii autorstwa Elżbiety Minczakiewicz [1998], w której przedstawiony został historyczny rozwój logopedii w poszczególnych ośrodkach w Polsce oraz Proces instytucjonalizacji zawodu logopedy w Polsce: zarys problemu Danuty Dramskiej [2001], w której został opisany rozwój zawodu logopedy.

Początkowo podstawową formą kształcenia logopedów były studia podyplomowe, czyli pomagisterskie. Dopiero w 1989 roku powstały pierwsze pięcioletnie studia logopedyczne jako specjalność na kierunku pedagogika specjalna w Akademii Pedagogiki Specjalnej im. Marii Grzegorzewskiej w Warszawie. Później ta forma kształcenia była stosowana na innych uczelniach jako specjalność pedagogiki lub filologii polskiej. W 1991 roku dzięki zaangażowaniu Leona Kaczmarka, Haliny Mierzejewskiej, Stanisława Grabiasa i Marii Przybysz-Piwko powstało Polskie Kolegium Logopedyczne (PKLog), którego podstawowymi celami były: wymiana doświadczeń na temat form kształcenia logopedycznego i ramowych programów studiów, wypracowanie w tym zakresie wspólnego stanowiska ośrodków akademickich, logopedycznych towarzystw naukowych, związku zawodowego, a także prezentowanie stanowiska w kontaktach z ministerstwami z zakresu zdrowia i edukacji. W 1996 roku zawód logopedy został wpisany na listę zawodów w Polsce. W 1997 roku PKLog zatwierdziło liczby godzin kształcenia: 600 godzin na dwuletnich studiach podyplomowych oraz 1200 godzin na studiach pięcioletnich. Przyjęte ustalenia stawały się fundamentalnym kryterium oceny kształcenia w zakresie logopedii jako przygotowującego do wykonywania zawodu logopedy [Przybysz-Piwko, Szamburski, 2010, s. 16-17].

Spośród przepisów prawnych regulujących kształcenie logopedów wymienić należy:

1. Rozporządzenie Ministerstwa Edukacji Narodowej z dnia 12 marca 2009 r. w sprawie szczegółowych kwalifikacji wymaganych od nauczycieli oraz 
określenia szkół i wypadków, w których można zatrudnić nauczycieli niemających wyższego wykształcenia lub zakładu kształcenia nauczycieli (Dz.U. Nr 50, poz. 400):

Według $₫ 2$ tego rozporządzenia kwalifikacje do zajmowania stanowiska nauczyciela logopedy w szkołach i placówkach, o których mowa $\mathrm{w} \$ 2$, posiada osoba, która ukończyła:

1) studia magisterskie w zakresie logopedii oraz posiada przygotowanie pedagogiczne lub

2) studia magisterskie na dowolnym kierunku i studia podyplomowe w zakresie logopedii oraz posiada przygotowanie pedagogiczne.

Kwalifikacje do zajmowania stanowiska nauczyciela logopedy w szkołach i placówkach, o których mowa w $\$ 3,4,14,15,17$ i 18, posiada osoba, która:

1) ma kwalifikacje określone $w \$ 2$ lub

2) ukończyła:

a) studia I stopnia $\mathrm{w}$ zakresie logopedii oraz posiada przygotowanie pedagogiczne lub

b) studia I stopnia na dowolnym kierunku (specjalności) i studia podyplomowe w zakresie logopedii oraz posiada przygotowanie pedagogiczne.

2. Rozporządzenie z dnia 7 stycznia 2003 r. w sprawie zasad udzielania i organizacji pomocy psychologiczno-pedagogicznej w publicznych przedszkolach, szkołach i placówkach ( $\$ 15$, ust. 5, Dz.U. Nr 11, poz. 114) [Przybysz-Piwko, Szamburski, 2010].

3. Rozporządzenie Ministra Zdrowia z dnia 30 września 2002 r. w sprawie uzyskiwania tytułu specjalisty $\mathrm{w}$ dziedzinach mających zastosowanie $\mathrm{w}$ ochronie zdrowia.

$\$ 1$ tego rozporządzenie określa:

1) rodzaje zawodów, w których może być uzyskiwany tytuł specjalisty oraz wykaz dziedzin mających zastosowanie w ochronie zdrowia;

2) podmioty uprawnione do prowadzenia szkoleń i nadawania tytułu specjalisty;

3) szczegółowe zasady, warunki i tryb uzyskiwania tytułu specjalisty.

W myśl $\$ 2$ ilekroć w rozporządzeniu jest mowa o specjalizacji - rozumie się przez to rodzaj szkolenia w ramach kształcenia podyplomowego, mający na celu uzyskanie specjalistycznych kwalifikacji w określonej dziedzinie mającej zastosowanie w ochronie zdrowia i uzyskanie tytułu specjalisty w tej dziedzinie [Przybysz-Piwko, Szamburski, 2010].

Kandydaci na studia logopedyczne zobowiązani są przedstawić zaświadczenie od specjalisty logopedy o braku przeciwwskazań do wykonywania zawodu lub $\mathrm{w}$ trakcie przyjmowania na studia przeprowadzany jest egzamin praktyczny dotyczący oceny artykulacji, fonacji, prozodii i budowy narządów jamy ustnej.

Obecnie, aby uzyskać uprawnienia do wykonywania zawodu logopedy, należy ukończyć [Dramska, 2001]: 
1) studia z zakresu logopedii, czyli: kierunek logopedia lub kierunek ze specjalnością logopedia (w systemie stacjonarnym lub niestacjonarnym), studia pierwszego lub drugiego stopnia (ważne, aby w ramach pierwszego stopnia uzyskać 800 godz., a w sumie 1200 godz.);

2) studia podyplomowe w liczbie 600 godz. z zakresu logopedii, trwające 4 semestry.

Dodatkowym dokumentem potwierdzającym posiadanie kwalifikacji zawodowych logopedy jest certyfikat wydawany przez Komisję ds. Certyfikatów na wniosek osoby zainteresowanej. Mogą go otrzymać wszyscy czynni zawodowo logopedzi, którzy w zawodzie przepracowali co najmniej dwa lata. Jego ważność utrzymuje się przez 5 lat od momentu jego wydania, natomiast 10 lat od aktualizacji [Polski Związek Logopedów].

Warto jednak zauważyć, że uczelnie nie mają ujednoliconego programu studiów w zakresie logopedii, co znacząco wpływa na różnorodny poziom wiedzy i doświadczenia logopedów.

Obecnie nad logopedią w Polsce czuwają dwie instytucje: Polskie Towarzystwo Logopedyczne, które zajmuje się między innymi rozwojem naukowym, zabiega o współpracę międzynarodową i pozycję polskiej logopedii na świecie, oraz Polski Związek Logopedów, który dba o warunki pracy i określa standardy kształcenia logopedów.

Analizując kształtowanie się nauki, jaką jest logopedia, należy także podkreślić, że w XXI wieku wydawnictwo Harmonia Universalis, przy współpracy z Katedrą Logopedii Uniwersytetu Gdańskiego, zaczęło wydawać serię publikacji logopedycznych związanych z metodologią badań, diagnozą logopedyczną i poszczególnymi specjalnościami w logopedii. Ponadto w Polsce wydawane są czasopisma naukowe, w których prezentowane są między innymi wyniki badań nad opisem rozwoju i zaburzeń mowy, znajdujące zastosowanie w standardach postępowania logopedycznego. Wśród tych czasopism można wymienić następujące: „Logopedia”, „Forum Logopedyczne”, „Biuletyn Logopedyczny”, „Studia Logopaedica”, „Neurolingwistyka Praktyczna”, „Logopaedica Lodziensia”, „Studia Pragmalingwistyczne”.

Warto także docenić organizację konferencji logopedycznych o randze ogólnopolskiej i międzynarodowej, które odbywają się między innymi w Warszawie, Lublinie, Toruniu, Bydgoszczy czy też na Śląsku. Przykładem takich konferencji jest coroczna międzynarodowa konferencja logopedyczna „Zaburzenia płynności mowy. Teoria i praktyka", organizowana przez Uniwersytet Śląski w Katowicach lub ogólnopolska konferencja logopedyczna z cyklu „Terapia, wspomaganie, wsparcie - różne drogi, jeden cel”, organizowana cyklicznie przez Katedrę Logopedii Uniwersytetu Mikołaja Kopernika w Toruniu z okazji Europejskiego Dnia Logopedy.

Wszystkie wyżej wymienione działania wskazują na to, że logopedia jest dyscypliną rozwojową ${ }^{1}$. Często podkreślana jest jej interdyscyplinarność i związek

1 Można też mówić o logopedii jako o subdyscyplinie pedagogiki, pedagogiki specjalnej i o jej powiązaniu z językoznawstwem. 
z innymi naukami [Kaczmarek, 1991; Hamerlińska-Latecka, Karwowska, 2014]. W ostatnim czasie wzrosło zainteresowanie nową specjalnością logopedyczną, jaką jest onkologopedia, czyli specjalnością powiązaną z onkologią - nauką dotyczącą chorób nowotworowych. Należy jednak zauważyć, że powołanie tej specjalności jest efektem wcześniejszych dokonań naukowych logopedów, między innymi Anny Żebryk-Stopy, Hanny Owczarzak, Małgorzaty Stecewicz, Doroty Lipiec, Małgorzaty Fabczak.

\section{Onkologopedia - uzasadnienie powstania i przedmiot badań}

Termin onkologopedia po raz pierwszy został użyty w 2012 roku w monografii $M e$ dycyna w logopedii pod redakcją Jacka Błeszyńskiego, w rozdziale Agnieszki Hamerlińskiej-Lateckiej: Onkologopedia - o potrzebie utworzenia nowej specjalności logopedycznej [Hamerlińska-Latecka, 2012], który był pokłosiem konferencji naukowej „Medycyna w logopedii”, zorganizowanej przez Wydział Nauk Pedagogicznych UMK w Toruniu. W 2013 roku został opublikowany tekst Onkologopedia dziecięca - kierunek badań logopedii [Hamerlińska-Latecka, 2013], a z kolei w 2015 roku powstała pierwsza monografia z tego zakresu: Onkologopedia - logopedia wobec chorób nowotworowych [Hamerlińska-Latecka, 2015]. Poza tym w publikacji z 2014 roku pod redakcją Stanisława Milewskiego, Jerzego Kuczkowskiego, Katarzyny Kaczorowskiej-Bray Biomedyczne podstawy logopedii pojawiły się dwa rozdziały powiązane z zaburzeniami mowy o podłożu choroby nowotworowej, pierwszy - Choroby nowotworowe głowy i szyi a zaburzenia mowy autorstwa Krystyny Serkies i drugi - Rehabilitacja głosu i mowy po operacjach krtani autorstwa Anny Sinkiewicz i Hanny Mackiewicz.

W 2016 roku w czasopiśmie „Neurolingwistyka Praktyczna” w sekcji „Listy do redakcji” pojawiło się pytanie „Czym jest onkologopedia? Jaki jest sens wyodrębniania tej specjalności logopedycznej?” zadane przez Emilię Lech, studentkę filologii polskiej z logopedią z Uniwersytetu Pedagogicznego w Krakowie. Pytanie to jest jak najbardziej zasadne, ponieważ od lat w Polsce funkcjonował podział specjalności logopedycznych stworzony przez Leona Kaczmarka [1991], uwzględniający logopedię teoretyczną i stosowaną - praktyczną (ogólna: wychowawcza i artystyczna oraz specjalna: korekcyjna i surdologopedia). Ponadto dotychczas zaburzenia mowy o podłożu nowotworowym odnajdywały swoje miejsce w neurologopedii, na co wskazuje umieszczanie zagadnień onkologopedycznych w podręcznikach: Podstawy neurologopedii pod redakcją Grażyny Jastrzębowskiej, Elżbiety Szeląg, Tadeusza Gałkowskiego z 2005 roku oraz Wprowadzenie do neurologopedii pod redakcją Andrzeja Obrębowskiego z 2012 roku. Rozważania nad powstawaniem nowych specjalności, w tym onkologopedii, odnaleźć można w artykule Danuty Pluty-Wojciechowskiej z 2014 roku, gdzie autorka napisała: 
Wraz z rozwojem logopedii powstają różne działy tej nauki, wyodrębniane ze względu na różne kryteria. Należą do nich: neurologopedia, surdologopedia, balbutologopedia, oligofrenologopedia, logopedia artystyczna, wczesna interwencja logopedyczna, onkologopedia. Wyodrębnienie takich działów jest związane $\mathrm{z}$ uwzględnieniem różnych perspektyw, które pozwalają na „oświetlenie” pewnych zagadnień logopedycznych. Są nimi: przyczyna zaburzeń mowy pozwalająca na wydzielenie neurologopedii, surdologopedii, oligofrenologopedii, onkologopedii. Wyróżnienie balbutologopedii wiąże się z uwzględnieniem rodzaju objawu, a przyczyny wyłonienia się wczesnej interwencji logopedycznej należy upatrywać w uwzględnieniu kryterium wieku i związanej z nim podatności na działania stymulujące, wspierające i korygujące. Z kolei wyłonienie się logopedii artystycznej, logopedii medialnej jako działu logopedii wiąże się z uwzględnieniem innego kryterium, a mianowicie charakteru pomocy, jakiej potrzebuje pewna grupa osób w związku z wykonywanym zawodem [Pluta-Wojciechowska, 2014, s. 10-11].

Onkologopedia to specjalność logopedyczna zajmująca się diagnozą i terapią logopedyczną osób (dzieci, młodzieży i dorosłych) z objawami zaburzeń czynności prymarnych i sekundarnych wywołanych chorobą nowotworową i/lub wynikających z konsekwencji jej leczenia oraz obszar badań, dzięki któremu tworzona jest teoria logopedyczna [Hamerlińska-Latecka, 2015, s. 50]. Jak zostało podkreślone w Onkologopedii - logopedii wobec chorób nowotworowych [Hamerlińska-Latecka, 2015], powodem wyodrębnienia onkologopedii jest przede wszystkim specyfika pracy z pacjentami onkologicznymi - dorosłymi i dziećmi, która wydaje się być zdecydowanie inna niż z osobami z zaburzeniami mowy o podłożu neurologicznym. Narażenie na nawrót choroby jest zjawiskiem zaburzającym codzienne funkcjonowanie osób w okresie zdrowienia lub wyleczonych. Co więcej, w onkologii stosowane są także inne metody leczenia, które w neurologii nie są wykorzystywane, na przykład radioterapia i chemioterapia. Oznacza to, że specjaliści zajmujący się niesieniem pomocy pacjentom powinni być zorientowani, przez co pacjenci ci przechodzili lub przechodzą - zarówno w aspekcie medycznym (zastosowane zabiegi i leczenie), jak i psychologicznym (proces traumy, adaptacji i osiągania wglądu w chorobę) [Hamerlińska-Latecka, 2015, s. 50].

Ogólnym przedmiotem badań onkologopedii jest zjawisko występowania zaburzeń czynności prymarnych oraz sekundarnych, które powstają na skutek choroby nowotworowej lub w konsekwencji jej leczenia. Za zaburzone czynności prymarne przyjmuje się te, które odpowiadają za proces jedzenia (ssanie, gryzienie, kąsanie, połykanie) i oddychania. Z kolei zaburzonymi czynnościami sekundarnymi są te, które wiążą się z mową, mówieniem, komunikowaniem się. Ustalono także szczegółowe elementy przedmiotu badań nowej specjalności [Hamerlińska-Latecka, 2015, s. 68]:

1) profilaktyka zaburzeń mowy i połykania o podłożu nowotworowym;

2) rozwój mowy dziecka wyleczonego z choroby nowotworowej; 
3) mechanizm powstawania zaburzeń mowy i połykania na tle raka;

4) diagnoza zaburzeń;

5) terapia zaburzeń;

6) oddziaływanie zaburzeń na jakość życia i psychospołeczne funkcjonowanie niepełnosprawnych;

7) kompensowanie utraconych zdolności komunikacyjnych innymi umiejętnościami, które nie zostały utracone.

\section{Włączenie onkologopedii do systemu kształcenia logopedów}

Zdaniem Stanisława Milewskiego i Katarzyny Kaczorowskiej-Bray [2015, s. 14] obszar zagadnień, które leżą w kręgu zainteresowań logopedii, związany jest z czterema dziedzinami nauki (odpowiednimi dyscyplinami naukowymi): naukami humanistycznymi (językoznawstwem), naukami społecznymi (naukami o poznaniu i komunikacji społecznej, pedagogiką, psychologią), naukami biologicznymi (biologią) i naukami medycznymi (medycyną, stomatologią). Coraz częściej poszczególne specjalności logopedyczne powstają w powiązaniu z daną specjalizacją medyczną (rysunek 1), choć należy pamiętać, że istnieje ścisły związek logopedii z następującymi specjalizacjami medycznymi: neurologią, laryngologią, audiologią, foniatrią, psychiatrią, neonatologią, pediatrią, medycyną rehabilitacyjną.

Mając tytuł zawodowy logopedy, można rozwijać się dalej w wybranej przez siebie specjalności. Wymienia się: neurologopedię, surdologopedię, oligofrenologopedię (logopedię osób z niepełnosprawnością intelektualną), balbutologopedię [por. Minczakiewicz, 1997], wczesną interwencję logopedyczną [Kaczorowska-Bray, Milewski, 2016], logopedię artystyczną [Kamińska, Milewski, 2016] i gerontologopedię [Tłokiński, Milewski, Kaczorowska-Bray, 2018].

Jedną z wymienionych na rysunku 1 specjalności logopedycznych jest onkologopedia, która jest powiązaniem logopedii z onkologią oraz wynika ze współpracy z innymi specjalizacjami medycznymi: radiologią, neurologią, neurochirurgią, foniatrią i otorynolaryngologią.

Uniwersytet Kazimierza Wielkiego w Bydgoszczy w 2015 roku wpisał w program studiów na kierunku logopedia przedmiot onkologopedia. Ruch ten stanowił pierwszy krok ku rozpowszechnianiu wiedzy z zakresu zaburzeń mowy o podłożu choroby nowotworowej. Kolejną uczelnią stał się Uniwersytet Warmińsko-Mazurski w Olsztynie, na którym również w ramach kierunku logopedia zaczął być realizowany przedmiot onkologopedia. Na Uniwersytecie Mikołaja Kopernika w Toruniu zagadnienia onkologopedyczne zawarte są w przedmiocie terapia zaburzeń obwodowych mowy oraz afonia i dysfonia. 

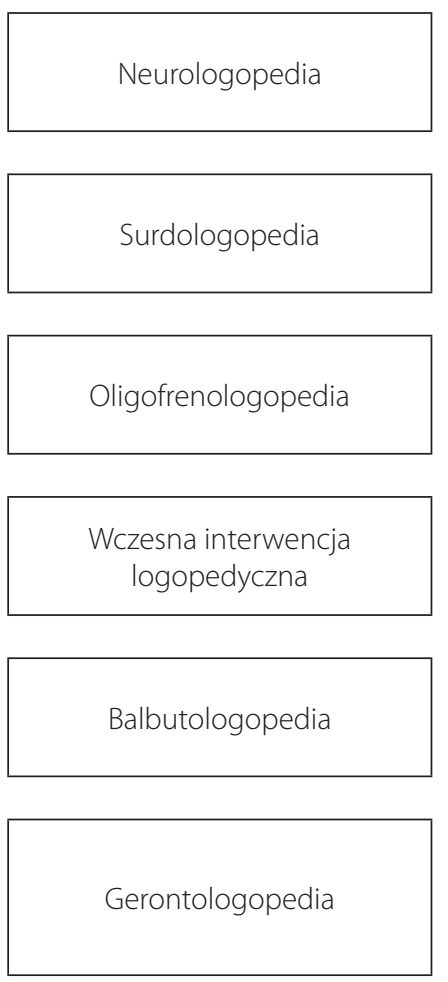

Logopedia artystyczna

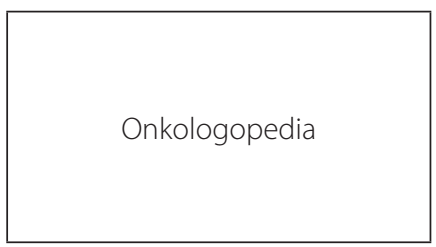

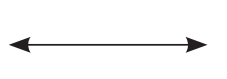
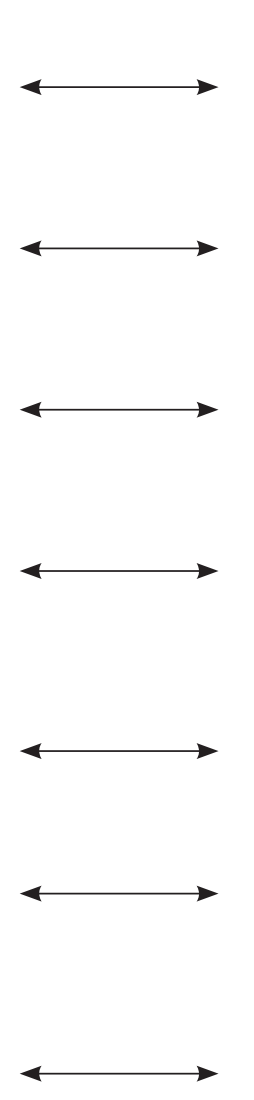
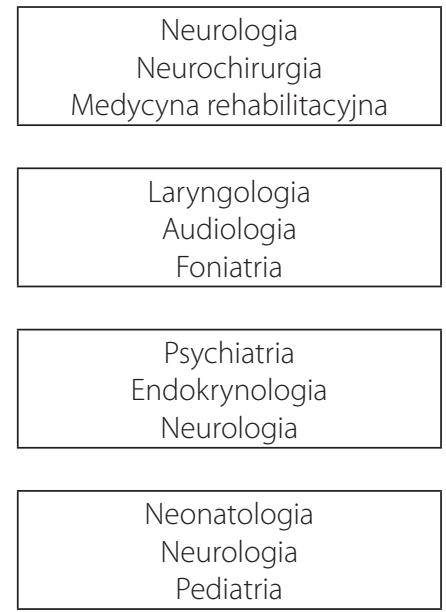

\begin{tabular}{|c|}
\hline Neurologia \\
Psychiatria \\
Foniatria \\
\hline
\end{tabular}
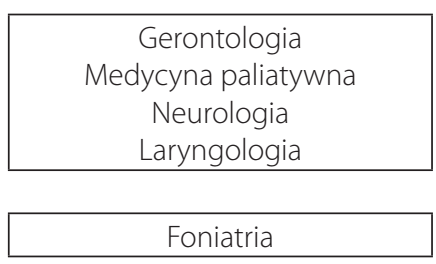

\begin{tabular}{|c|}
\hline Onkologia \\
Radiologia \\
Neurologia \\
Neurochirurgia \\
Otorynolaryngologia \\
Foniatria \\
\hline
\end{tabular}

Rysunek 1. Specjalności logopedyczne względem specjalizacji medycznych

Źródło: opracowanie własne.

Potwierdzeniem potrzeby włączenia onkologopedii w system kształcenia logopedów są wyniki badań zaprezentowane podczas obrony licencjatu z zakresu logopedii, którego autorką była Kamila Bujewska [2017]2 ${ }^{2}$ Oparła ona swoją pracę na metodologii badań pedagogicznych. Przedmiotem badań uczyniła postawy logopedów wobec terapii logopedycznej osób z nowotworami w obrębie głowy i szyi, a celem teoretycznym badań było opisanie tych postaw. Autorka zastosowała metodę sondażu

2 W 2017 roku na Wydziale Pedagogiki i Psychologii Uniwersytetu Kazimierza Wielkiego w Bydgoszczy podczas obrony licencjatu z zakresu logopedii Kamila Bujewska przedstawiła pracę pt. Postawy logopedów wobec terapii logopedycznej osób chorych na nowotwory w obrębie głowy i szyi, której promotorem była A. Hamerlińska. 
diagnostycznego, a techniką badań była samodzielnie opracowana ankieta. W badaniach wzięło udział 73 logopedów. Grupę badanych stanowiły kobiety w wieku od 21 do 51 lat (średnia 27 lat). Sposób uzyskania zawodu logopedy był różnorodny: $45,2 \%$ badanych uzyskało go dzięki studiom podyplomowym, $26 \%$ przez pięcioletnie studia jednolite (np. pedagogika, specjalność logopedia), 17,8\% ankietowanych ukończyło studia I stopnia (licencjackie), natomiast 11\% studia II stopnia (magisterskie) o specjalności logopedia. Badani logopedzi pracują w różnych miejscach - przede wszystkim w przedszkolach (47\%), szkołach podstawowych $(24,7 \%)$, prywatnych gabinetach (16,4\%), przychodniach (5,5\%) i szpitalach $(2,7 \%$.) Większość respondentów prowadzi zajęcia z udziałem dzieci (84,7\%); mniej z dorosłymi (13,9\%); a 1,4\% z młodzieżą. Uzyskano następujące wyniki:

1. Większość badanych - 80,8\% - nie prowadziła dotychczas terapii logopedycznej z udziałem osób po chorobie nowotworowej; 19,2\% prowadziło taką terapię ${ }^{3}$.

2. Logopedów zapytano o to, czy podjęliby się prowadzenia terapii logopedycznej z osobami z zaburzeniami na skutek nowotworu w obrębie głowy i szyi. Z badań wynika, że $47,9 \%$ ankietowanych podjęłoby się przeprowadzenia terapii, 30,1\% wskazało, iż nie wie, czy podjęłoby się współpracować podczas terapii z ową grupą pacjentów, a $21,9 \%$ respondentów wolałoby uniknąć prowadzenia terapii z osobami po nowotworze w obrębie głowy i szyi.

3. Respondenci zapytani o to, czy czują się wystarczająco przygotowani do prowadzenia terapii osób po chorobach nowotworowych, w większości stwierdzili, że nie czują się wystarczająco przygotowani do niesienia pomocy osobom z takimi trudnościami (61,6\%). Tylko 17,8\% respondentów czuje się wystarczająco przygotowanych, a 20,5\% ankietowanych nie jest w stanie ocenić swojego przygotowania.

4. Z uwagi na specyfikę pracy z pacjentem onkologicznym zapytano także o odczuwanie oporu psychicznego przed prowadzeniem terapii logopedycznej. $66,2 \%$ badanych odpowiedziało, że nie odczuwa oporu psychicznego. Zaledwie $7,7 \%$ wskazało, że odczuwałoby opór, a $26,1 \%$ ankietowanych nie potrafiło określić, czy odczuwałoby taki opór.

5. Ankietowanych zapytano o to, czy osobom z chorobami nowotworowymi w obrębie głowy i szyi potrzebna jest terapia logopedyczna. Wszyscy odpowiedzieli, że jeśli istnieje potrzeba, należy podjąć się prowadzenia terapii logopedycznej. Według badanych terapia powinna być przeprowadzana na oddziale otolaryngologii lub onkologii. Badane osoby zaznaczyły, że jeszcze przed operacją wskazane jest spotkanie $\mathrm{z}$ logopedą.

3 Może to wynikać ze specyfiki miejsca pracy - większość badanych osób pracuje w przedszkolu, a pacjenci onkologiczni zazwyczaj korzystają z pomocy logopedycznej w poradniach przyszpitalnych. 
6. W prowadzonych badaniach zwrócono także uwagę na moment rozpoczęcia terapii logopedycznej u pacjenta onkologicznego. Ankietowani odpowiedzieli, że terapia powinna być wdrożona jak najszybciej, czyli zaraz po zabiegach operacyjnych, po wygojeniu rany, a czasem też przed zabiegiem. Ponadto logopedzi podkreślali, że o skierowaniu do logopedy decyduje lekarz prowadzący.

W ramach podstawowego programu studiów logopedycznych pojawiają się zazwyczaj jedynie zagadnienia dotyczące terapii logopedycznej osób po usunięciu krtani. Jest to dość duże ograniczenie. Po pierwsze, onkologopedia dotyczy zaburzeń mowy i czynności prymarnych zarówno u dzieci, jak i dorosłych. Po drugie, zaburzenia mowy i połykania powstają nie tylko w przypadku raka krtani, choroba powodująca te trudności może być zlokalizowana także między innymi w jamie ustnej czy jamie nosowej. Po trzecie, istotne jest poznanie specyfiki nowotworów ośrodkowego układu nerwowego. Ponadto ważne jest, aby mieć rozeznanie, czym jest i jakie są konsekwencje radioterapii czy też chemioterapii.

Z przedstawionych wcześniej badań wynika, że ponad $60 \%$ badanych logopedów twierdzi, że nie jest wystarczająco przygotowanych do pracy z osobami z zaburzeniami mowy o podłożu nowotworowym. Jednocześnie respondenci zauważają, że osoby z chorobami nowotworowymi mogą potrzebować pomocy logopedy.

Autorka niniejszego artykułu pragnie zauważyć, że by móc zgłębiać obszar onkologopedii, wymagane powinno być posiadanie podstawowego wykształcenia logopedycznego. Sam przedmiot onkologopedia jak najbardziej powinien pojawić się w programie studiów na kierunku logopedia, a jego rozwinięcie powinno być realizowane jako kształcenie podyplomowe uwzględniające obszar medyczny, psychoonkologiczny, językoznawczy i logopedyczny. Wówczas w siatce przedmiotów studiów podyplomowych należałoby umieścić zagadnienia związane z:

1) podstawami onkologii, laryngologii onkologicznej, chirurgii onkologicznej,

2) onkologopedią, czyli opisem przedmiotu i celu tej specjalności,

3) przedmiotami logopedycznymi, które muszą dotyczyć diagnozy i terapii, takimi jak afonia i dysfonia po raku krtani, dyslalia po raku jamy ustnej (i nie tylko), afazja i dysfazja po guzach mózgu, dysfagia nowotworowa,

4) metodami leczenia stosowanymi w onkologii: radioterapią i chemioterapią,

5) pielęgnacją rurki tracheostomijnej i jamy ustnej,

6) elementami terapii psychoonkologicznej,

7) podstawami medycyny paliatywnej,

8) fizjoterapią.

Warto również pamiętać o terapii pedagogicznej, dydaktyce nauczania czy pracy socjalnej, które mogą poszerzyć wiedzę i doświadczenie logopedy. 


\section{Podsumowanie}

Rak to choroba groźna, dotykająca wiele osób - bez względu na wiek. Jak zostało przedstawione w niniejszym artykule, liczba osób, u których dochodzi do zachorowania na nowotwór jest bardzo wysoka. Wraz z postępem medycyny i technik diagnozowania wzrasta także liczba osób uratowanych, wyleczonych. Niestety, po chorobie nowotworowej wiele czynności życiowych ulega utraceniu lub przekształceniu. Często dochodzi do powstania zaburzeń mowy, trudności w połykaniu. Po okresie leczenia pacjenci, chcąc dbać o jakość swojego życia, pragnąc wyraźniej mówić czy jeść, mogą szukać pomocy. Osobą, która powinna się włączyć w proces zdrowienia, jest logopeda. W prezentowanych badaniach logopedzi nie obawiają się niesienia pomocy osobom z chorobą nowotworową. Cenne jednak jest to, że potrafią przyznać się do braku wiedzy w zakresie standardów postępowania logopedycznego w przypadku etiologii onkologicznej.

Praca z osobami, których dotknęła choroba śmiertelna, wymaga odpowiedniego podejścia i empatii. Celem pracy logopedów miałoby być przede wszystkim nauczenie mowy zastępczej (np. w przypadku usunięcia krtani), terapia głosu w przypadku konsekwencji mikrochirurgicznych operacji krtani, usprawnianie narządów jamy ustnej kompensujących powstałe ubytki w celu uzyskania lepszej artykulacji, prowadzenie terapii afazji i/lub dysartrii, których przyczyną były guzy mózgu, prowadzenie terapii czynności pokarmowych w przypadku wystąpienia dysfagii. Logopedzi pracujący z osobami po chorobie nowotworowej powinni posiadać także wiedzę z zakresu metod leczenia stosowanych w onkologii, by wiedzieć, jakie mogą być konsekwencje ich stosowania. Ponadto powinni umieć rozpoznawać objawy niepożądanych stanów psychicznych, na przykład depresji, by móc dostrzec konieczność pomocy innych specjalistów, w tym psychoonkologów. Cenną wiedzą byłaby też ta związana na przykład z pielęgnacją jamy ustnej po radioterapii czy pielęgnacją rurki tracheostomijnej. Są to zagadnienia, które warto poruszać w trakcie kształcenia logopedów, którzy mieliby nieść pomoc osobom żyjącym z konsekwencjami choroby nowotworowej w obrębie mózgu, głowy i szyi. Dlatego też, zdaniem autorki, istnieje konieczność zaistnienia onkologopedii w systemie kształcenia podyplomowego dla logopedów. A w ramach podstawowego kształcenia onkologopedia może być realizowana jako przedmiot ogólny. 
Literatura

Bujewska Kamila, 2017, Postawy logopedów wobec terapii logopedycznej osób chorych na nowotwory w obrębie głowy i szyi, niepublikowana praca licencjacka, promotor A. Hamerlińska, Wydział Pedagogiki i Psychologii Uniwersytetu Kazimierza Wielskiego w Bydgoszczy, Bydgoszcz.

Didkowska Joanna, Wojciechowska Urszula, Olasek Paweł, 2017, Nowotwory złośliwe w Polsce w 2015 roku, Warszawa: Ministerstwo Zdrowia.

Dramska Danuta, 2001, Proces instytucjonalizacji zawodu logopedy w Polsce, Katowice: Uniwersytet Śląski.

Gałkowski Tadeusz, Szeląg Elżbieta, Jastrzębowska Grażyna (red.), 2005, Podstawy neurologopedii, Opole: Uniwersytet Opolski.

Hamerlińska-Latecka Agnieszka, 2012, Onkologopedia - o potrzebie powołania nowej specjalności, [w:] J. Błeszyński (red.), Medycyna w logopedii, Gdańsk: Harmonia, s. 57-66.

Hamerlińska-Latecka Agnieszka, 2013, Onkologopedia dziecięca - kierunek badań logopedii, [w:] M. Babiarz, M. Rutkowski (red.), Dziecko ze specjalnymi potrzebami edukacyjnymi - pedagogiczne dylematy przestrzeni rozwoju integralnego, Kielce: Uniwersytet Jana Kochanowskiego w Kielcach, s. 195-216.

Hamerlińska-Latecka Agnieszka, 2015, Onkologopedia - logopedia wobec chorób nowotworowych, Bydgoszcz: Wydawnictwo Uniwersytetu Kazimierza Wielkiego w Bydgoszczy.

Hamerlińska-Latecka Agnieszka, Karwowska Małgorzata, (red.), 2014, Interdyscyplinarność w logopedii, Gliwice: Komlogo.

Kaczmarek Leon (1991), Model opieki logopedycznej w Polsce (Projekt), Gdańsk: Gdański Związek Logopedów.

Kaczorowska-Bray Katarzyna, Milewski Stanisław (red.), 2016, Wczesna interwencja logopedyczna, Gdańsk: Harmonia Universalis.

Kamińska Barbara, Milewski Stanisław (red.), 2016, Logopedia artystyczna, Gdańsk: Harmonia Universalis.

Milewski Stanisław, Kaczorowska-Bray Katarzyna, 2015, Wstęp, [w:] ciż (red.), Metodologia badań logopedycznych z perspektywy teorii i praktyki, Gdańsk: Harmonia Universalis, s. 14-22.

Milewski Stanisław, Kuczkowski Jerzy, Kaczorowska-Bray Katarzyna (red.), 2014, Biomedyczne podstawy logopedii, Gdańsk: Harmonia Universalis.

Minczakiewicz Elżbieta, 1997, Logopedia. Mowa, rozwój, zaburzenia, terapia, Kraków: Wydawnictwo Naukowe Akademii Pedagogicznej.

Minczakiewicz Elżbieta, 1998, Początki i rozwój polskiej logopedii, Kraków: Wydawnictwo Edukacyjne.

Obrębowski Andrzej (red.), 2012, Wprowadzenie do neurologopedii, Poznań: Termedia.

Pluta-Wojciechowska Danuta, 2014, Gerontologopedia, „Forum Logopedyczne”, nr 22, s. 9-14.

Polski Związek Logopedów, http://www.logopeda.org.pl (dostęp: 24.08.2018).

Porayski-Pomsta Józef, Emiluta-Rozya Danuta, 2018, Logopedia warszawska - historia i czasy współczesne, „Studia Pragmalingwistyczne”, t. X [w druku].

Przybysz-Piwko Maria, Szamburski Krzysztof, 2010, Standardy godzinowe kształcenia logopedów po zmianach, związanych z przyjęciem bolońskiego systemu oświaty, „Biuletyn Logopedyczny”, nr 1, s. 16-17.

Styczek Irena, 1970, Zarys logopedii, Warszawa: Państwowe Wydawnictwo Naukowe.

Tłokiński Waldemar, Milewski Stanisław, Kaczorowska-Bray Katarzyna (red.), 2018, Geronotologopedia, Gdańsk: Harmonia Universalis. 


\section{Streszczenie}

Onkologopedia, nowa specjalność logopedyczna, jest wynikiem wieloletniego kształtowania się logopedii jako nauki. W artykule przedstawiono zarys rozwoju logopedii oraz proces instytucjonalizacji zawodu logopedy w Polsce. Następnie opisano przedmiot badań onkologopedii i przedstawiono wyniki badań dotyczących postaw logopedów wobec terapii logopedycznej osób z zaburzeniami mowy i czynności prymarnych o podłożu choroby nowotworowej. Przyjąć można, że włączenie w system kształcenia logopedów przedmiotów $\mathrm{z}$ zakresu onkologopedii jest istotnym kierunkiem rozwoju nauki.

\section{Summary}

In the beginning, the outline of speech therapy development and the process of institutionalization of the speech therapy in Poland will be characterized. This was done because oncology, a new speech therapy specialty, is the result of many years of speech therapy as a science. Next, the subject of oncologopedy research was described and the results of research on the attitudes of speech therapists towards speech therapy and speech disorders and primary activities caused by cancere were presented. It can be assumed that inclusion of oncologopedy in the vocational education of speech therapists, is an important direction in the development of science. 